\title{
THE JUDICIAL CODE OF UNITED STATES WITH SOME INCIDENTAL OBSERVATIONS ON ITS APPLICATION TO HAWAII ${ }^{1}$
}

In so far as the Territory of Hawaii is concerned, the Judicial Code of the United States, which went into effect on January Ist, 1912, is of comparatively trifling importance. The greatest changes in procedure made by the Act were consequent upon the abolishment of Circuit Courts and the transfer of the jurisdiction of the Circuit Courts to the District Courts. The District Court of the Territory of Hawaii is a Court with the combined jurisdiction of the Circuit and District Courts of the United States, as they existed at the time of the adoption of the Organic Act. It will thus be seen that Congress, perhaps unwittingly, has adopted for use throughout the United States the same plan relative to the Courts as it adopted when the Hawaiian Court was established.

As I have said, the most material change effected by the Judicial Code is the abolishment of Circuit Courts.

To grasp fully the results of the change, and to understand the reasons which prompted Congress to make it, a brief study of the entire judicial system of the United States from the time of its organization is useful and instructive as well as interesting.

The Constitution vests the judicial power of the United States in a Supreme Court, and in such inferior Courts as Congress may from time to time ordain and establish. On the first day of the opening of the first Congress of the United States a bill was introduced in Congress which became a law in September, I789. It organized and defined the jurisdiction of the Supreme Court, and likewise established District Courts, one for each State of the Union. As the Supreme Court of the United States consisted of the chief justice and five associate justices, and there was one judge for each of the districts, there were in all nineteen judges provided for. The bill then grouped the districts into three circuits, and established in each circuit, Circuit Courts, with juris=

1 Read before the Bar Association of the Hawaiian Islands, June 15, 1912. The author frankly admits the gathering of his data from Congressional debates, and claims merit only for cutting it from a mass of other matter where its interesting features might be lost. 
diction in both civil and criminal cases, and also with an extensive appellate jurisdiction from the District Court. These Circuit Courts were made by the law to consist of two Supreme Court judges and a district judge. It will be noted that the office of circuit judge was not created, and indeed, did not come into existence until 1869 .

The workings of the system under this judiciary act may be observed with interest in many of the cases reported in Federal Cases. The justices of the Supreme Court traveled from district to district, and presided in many of the very important cases of the early days of the Republic. As is well known, Chief Justice Marshall presided as a member of the Circuit Court in the trial of Aaron Burr for treason at Richmond, Virginia.

Students of the question lay much stress upon the working of the early Circuit Courts. Naturally more or less jealousy existed in the various States concerning the Supreme Court, and its functions and great importance were for a considerable length of time not fully understood. Trials in the Circuit Courts, however, served to bring home to the people the dual system provided by the Constitution, and as the Courts were held within the States, and as there was always as a member of the bench a district judge appointed from the State, the suspicion incident to the exercise of power by the general government naturally lessened and gradually the plan came to be heartily approved. The holding of the Circuit Courts in the various districts was an event looked forward to, and the operation of the law closely studied by the people. In passing, it might be of interest to quote from an old New Hampshire newspaper a description of one of the first meetings of a Circuit Court within that State:

"Circuit Court. On Monday last the Circuit Court of the United States was opened in this town. The Hon. Judge Paterson presided. After the jury was impaneled the judge delivered a most elegant and appropriate charge. The law was laid down in a most masterly manner. Politics were set in their true light by holding up the Jacobins as the disorganizers of our happy country and the only instruments of introducing discontent and dissatisfaction among the well-meaning parts of the community. Religion and morality were pleasingly inculcated and enforced as being necessary to good government, good order, and good laws; for 'when the righteous are in authority, the people rejoice.'

"We are sorry that we could not prevail upon the honorable judge to furnish a copy of said charge to adorn the pages of the United States Oracle. 
"After the charge was delivered, the Rev. Mr. Alden addressed the throne of grace in an excellent and well adapted prayer."

As the country expanded and new grounds for the exercise of Federal jurisdiction were developed, there were naturally some changes in the operation of the Court. About three years after the passage of the first act, the law was modified in such a way as to obviate the constant attendance of the justice of the Supreme Court upon the sessions of the Circuit Court. In I793 a law was passed limiting to one instead of two the number of Supreme Court justices who should compose the Circuit Coutt, an action made necessary by the growth of the docket of the Supreme Court itself. As time passed and the population and business of the country increased, and new cases of Federal jurisdiction arose, a reorganiation of the system became necessary, and in 1869 was effected. By an act passed that year, a circuit judge in each of the mine circuits then existing was created, with the same power as possessed by the justice of the Supreme Court allotted to that circuit. It was further provided that the Circuit Court in each circuit should be held by the justice of the Supreme Court allotted to that circuit, or by the circuit judge, or by the judge of that district, sitting alone. The duties of the Supreme Court justice in the Circuit Court were limited to a visit once in two years. The changes made detracted somewhat from the dignity of the Circuit Court, but added to its usefulness by the addition of a circuit judge who would always be present in the circuit. The line of demarcation between the Circuit Court and the District Court was less strictly drawn by the provision that the district judge might alone exercise the powers of the Court.

Thus continued the judicial system of the United States from the year 1869 to the year 1890 . The operation of the law during these years is worthy of notice in a study of the reasons for the adoption of the law of 1890 , as well as of the adoption of the new code. The Supreme Court justices, occupied by the increasing number of appeals, seldom participated in the holding of the Circuit Courts, and the Circuit Courts were largely occupied with an extensive appellate jurisdiction from the District Courts. Much of the time of the circuit judges appointed under the provisions of the act, was consumed in a consideration of these appeals. The Circuit Court had jurisdiction on appeal of all cases arising in the District Court where the sum involved exceeded the sum of $\$ 50.00$, and in admiralty and maritime jurisdiction where the .amount involved exceeded $\$ 300.00$. The result was that the cir- 
cuit judges gradually withdrew from the cases involving original jurisdiction, and the Circuit Court in a large percentage of such cases was rarely presided over by the circuit judge. From the decisions of the Circuit Court, in nearly all cases, an appeal could be taken to the Supreme Court of the United States. Again, owing to the growth of business, was the result a crowded docket of that Court.

A demand for relief came from all parts of the country, and in 1890 a bill was introduced in .Congress to relieve conditions.

As the bill passed the House of Representatives, it practically abolished the Circuit Courts, since it took from them all their original jurisdiction and vested it in the District Court, and took from them all appellate jurisdiction and vested it in a new Court to be called the Circuit Court of Appeals, to consist of three judges in each circuit. The jurisdiction of this latter Court was to be wholly appellate, a jurisdiction made up of the appellate jurisdiction of the Circuit Court and certain appellate jurisdiction of the Supreme Court of the United States. When the bill reached the Senate, a different method was devised for relieving. the pressure in the Supreme Court. The nine new Appellate Courts were established, but the Circuit Court remained; with original jurisdiction as then existing. These amendments in the Senate were acquiesced in by the House only because the session of Congress was closing, and the necessity for relief of the Supreme Court was great. The amendments were concurred in and the bill became a law.

$\mathrm{UP}_{\mathrm{p}}$ to the adoption of the code under discussion we see, therefore, that the United States Courts consisted of the following: One Supreme Court, consisting of a chief justice and eight associate justices. Nine Circuit Courts of Appeal, one in each judicial Circuit, consisting of three judges each, which might be composed of the chief justice of the United States, the associate justice allotted for the circuit, the circuit judges within the circuit and the district judges within the circuit, any two of whom would consitute a quorum. There were seventy-seven Circuit Courts, one in each judicial district, required by various acts of Congress to be held in two hundred and seventy-six different places in the circuit. There were seventy-seven District Courts, required by various acts of Congress to be held in two hundred and seventysix different places. There were twenty-nine circuit judges, qualified by law to perform the work both of the Circuit Courts 
and the Circuit Courts of Appeal. There were ninety district judges, required by law to perform the entire work of the District Court, and qualified to hold a Circuit Court, sitting alone, and by the Act of $189 \mathrm{I}$ made a constituent part of the Circuit Court of Appeals.

From I89I to the time of the adoption of the code, the Courts operated under a system the complicity of which demonstrated beyond question the need of reform in the direction of simplicity. From time to time, as Congress enacted laws for the enforcement of which resort to the Courts of the United States was necessary, the jurisdiction conferred was nearly always concurrent. The jurisdiction of the two Courts was distinguished by no controlling principle. Take, for instance, in criminal cases. Both Courts had jurisdiction as to many crimes, except that the Circuit Court had exclusive jurisdiction in capital cases. In 1896 , while a partner of the then United States District Attorney for the District of Wyoming, $I$ assisted in the prosecution of criminal cases. The trials were all held in the same room, presided over by the same judge, with the same clerk and other Court officials. One of the cases was a murder case arising on the Shoshone Indian reservation. The indictment had been returned into the District Court, and by formal order transferred to the Circuit Court, and the case was tried there. Several other cases were tried, for crimes other than murder, some of them being of Federal jurisdiction, because committed on the same Indian reservation. These were tried in the District Court. Time and time again would the presiding judge have Court opened as a Circuit Court, and after the calling of the docket, have that Court closed with due solemnity. Immediately afterwards the crier would annourice that the District Court was in session. There would be a switching of dockets, and the District Court would proceed to business.

Rarely would a circuit judge preside at a Circuit Court. The appellate work was so great that the judges were occupied almost exclusively as members of the Circuit Court of Appeals. Pethaps, too, the provision of the law of 1890 making a circuit judge ineligible to sit as a nember of the Circuit Court of Appeals in cases on appeal in which he had participated in the trial, had something to do with this. "In only about ten per cent of the cases of which the Circuit Court had jurisdiction did the circuit judge preside, and in no less than twenty-two States Circuit Courts were held exclusively by the district judges. It might be 
said, too, that better results were obtained where the Circuit Court was presided over by a District Court judge. He was a resident of the State in which the cause of action usually arose, acquainted with conditions, and in many ways better qualified as a trial judge than one comparatively a stranger in the district.

To use the language of the framers of the bill, the system in force at the time of the adoption of the judicial code was "cumbersome, impracticable, confusing and expensive." The same framers, in commenting on the system provided for by the code, said that the new system was simple, concrete, elastic and logical; that it eliminated a Court of original jurisdiction wholly unnecessary, and in practical operation long since fallen into disuse. It did not displace a single judge or change the general practice of the Courts. It simplified the proceedings by consolidating jurisdiction and by having all cases in Courts of first instance, and all pleadings filed therein, brought and filed in the District Court; it preserved the same plan of judicature originally designed by the framers of the Constitution, and adopted by most of the States, to wit, one Court of original jurisdiction, an intermediate Court of appellate jurisdiction,--final in many cases,-and the Supreme Court as the Court of last resort.

Beyond this fundamental change by which the Circuit Courts were abolished, the code itself made no changes of a startling nature. Naturally there were in existence many inconsistent statutes relative to practice, and the framers of the code simply aimed to bring these conflicting, varying provisions into a consistent whole, if possible, and where not possible, to substitute some provision best suited to conditions. On the whole, the changes in the practice, save on the jurisdictional question, are not worth mentioning. The outcry against the actions of some Courts in the matter of injunctions and receiverships, and the agitation on the mainland consequent upon differences between capital and labor, led to some safeguards concerning the issuance of ex parte orders in injunction and receivership cases.

Cases like these are the only ones in which changes of any particular moment occur. A new provision has been inserted under.which a judge may be disqualified by an affidavit of prejudice, something new in Federal practice. This, however, is of but little interest here, for even if cases should arise where counsel may consider one of the Federal judges prejudiced, yet the statute is so worded that the remaining judge would be qualified to pre- 
side. Of local interest, perhaps, is a provision settling the much mooted question as to whether a judge who had been of counset in the matter was qualified. The statute absolutely disqualifies him.

Hawaii's distinctive place in the act is peculiar. I think it is reasonably clear that all of the provisions not directly inapplicable will prevail in the Court here, although the framers of the act in referring to this Territory did it in such a manner as to carefully distinguish between Constitutional Courts and Statutory Courts. The language used is of such a nature as to plainly preclude any claim that the United States District Court for Hawaii is a Court of the United States within the meaning of the Constitution.

Although the code has been in operation but a short time, its workings appear to be satisfactory. Complaints about it, as. evinced by amendments offered in Congress, are but few, and many of them arise from the fact that the act did legislate a few clerks of Court out of office. The act itself of course embraces. the Commerce Court, but the present indications are that this Court will be abolished by the present Congress. ${ }^{2}$ There is, however, one amendment pending of rather a revolutionary nature. A bill, which has already passed the House, and is now pending in the Senate, seeks to embody in the code a provision quite similar to that adopted by the State of California concerning appeals. ${ }^{3}$ It provides that the Appellate Courts of the United States shall affirm judgments, notwithstanding errors with relation to the admission of testimony and the giving of instructions to the jury, if the Court on the whole is satisfied from the record that substantial justice has been done.

This paper, in so far as Hawaii is concerned, need not have been read to you at all. The subject of "changes made by the judicial code" might have been read, and the paper have answered its purpose by containing but one sentence,-- "In so far as Hawaii is concerned the judicial code has made no change." However, the study is an interesting one. In these days of departures from old ideas concerning government, and of proposals which mean an entire recasting of our form of government, if they mean anything

2 Appropriation continued only to March 3, 1913, with probability that Court will be abolished. This only after a veto by President urging continuance of Court.

3 Passed House. Will come up in Senate next session. 
at all, it is rather refreshing to note that some lawyers and judges are not favorably impressed with revolutionary ideas. The new judicial code is a reversion rather than a revolution. Under its provisions the Federal Court system in the United States is in principle to all intents and purposes what it was more than a hundred years ago.

Robert W. Breckons.

United States District Attorney, District of Hazvaii. 